\title{
Tissue Accumulation of Arsenic Compounds in Aquacultural and Wild Mullet (Mugil cephalus)
}

\author{
C.-W. Liu, ${ }^{1}$ K.-H. Lin, ${ }^{2}$ C.-S. Jang ${ }^{1}$
}

${ }^{1}$ Department of Bioenvironmental Systems Engineering, National Taiwan University, Taipei, Taiwan 106

${ }^{2}$ Sustainable Environment Research Center, National Cheng Kung University,

Tainan, Taiwan 701

Received: 29 November 2005/Accepted: 12 May 2006

Mullet (Mugil cephalus) is a detritivorous fish. The fish has several edible tissues and a high economic value. The ovary of mature female mullet produces valuable mullet roe. Many wild mullet are present in the ocean around Taiwan from the middle of November to early February. Aquacultural mullet grows in inland ponds all year. According to statistical data in the Taiwanese Fishery Annual Report in 2002 (http://www.fa.gov.tw/), the total area of fishponds in which mullet is farmed is 613 hectares. The area of the ponds in the region of hyperendemic blackfoot disease is 378 hectares, or $62 \%$ of the total area of mullet aquaculture. Although most people who live in these areas do not drink water from wells, the groundwater is still used for aquaculture. In order to obtain more valuable mullet roe, a sex hormone, such as estradiol, is commonly added to the fish feed to promote feminization of growing young mullet in the ponds (Chang et al. 1995). This work surveys the contents of inorganic As (As(III) and As(V)), dimethylarsinic acid (DMA), monomethylarsonic acid (MMA) and total As in four edible tissues of mullet in the region of hyperendemic blackfoot disease in Taiwan. The difference between the As contents of the edible tissues of aquacultural and wild mullet are statistically analyzed and discussed.

\section{MATERIALS AND METHODS}

Aquacultural mullet samples were collected in Putai in December 2002. Twelve samples were taken from two aquacultural ponds (six samples per pond). Twelve wild mullet samples were purchased in Anpin harbor in December 2001 and 2002. The collected mullet samples were whole fish, and male and female fish were half of the samples.

The mullet samples were frozen and transported quickly from the field to the laboratory. The edible tissues, including the muscle in the dorsal fin, the stomach, the ovary in female mullet and the testis in male mullet, were analyzed. Aquacultural male mullet are feminized, so only the testis of wild male mullet was analyzed herein. A portion of the homogenized samples were freeze-dried for 36 $\mathrm{h}$ and prepared to analyze the total content of arsenic and arsenic species. About 
$0.5 \mathrm{~g}$ of homogenized freeze-dried samples and $25 \mathrm{ml}$ of $65 \%$ nitric acid were added to flask. They were boiled and digested for $12 \mathrm{~h}$ until the solution was clear. Total arsenic was analyzed using an electro-thermal atomic absorption spectrometer (AAS) (AA100 Perkin-Elmer Shelton, USA), and a hydride generator (HG) (FIAS 400 Perkin-Elmer Shelton, USA). $0.5 \% \mathrm{NaBH}_{4}$ in $0.25 \%$ $\mathrm{NaOH}$ and $1 \mathrm{~N} \mathrm{HCl}$ were added to $200 \mu \mathrm{l}$ of a digested sample to reduce the arsenic to arsine. Then, the total arsenic concentrations were determined by HG/AAS. $1.0 \sim 1.5 \mathrm{~g}$ of freeze-dried mullet including the dorsal fin, the stomach, the ovary in female mullet and the testis in mall mullet and $150 \mathrm{ml}$ of methanol/water solution $(1 / 1, \mathrm{v} / \mathrm{v})$ were placed into a Soxhlet extraction apparatus, modified from that described by Gomez-Ariza et al. (2000) and extracted for $16 \mathrm{~h}$. A methanol extraction tube was designed to remove the methanol when the extraction was complete. After the methanol was removed, the extract was freeze-dried to a powder and re-dissolved in $10 \mathrm{ml}$ of de-ionized water. The re-dissolved liquids were purified by filtering through $\mathrm{C}_{18}$ cartridges. A high-performance liquid chromatograph, HPLC (Hitachi 7110, Naka, Japan), equipped with an anion column (Machey-Nagel, Nucleosil, $10 \mu \mathrm{m}, 250 \times 4.6 \mathrm{~mm}$ ) and connected to HG/AAS, was used to separate As (III), As (V), MMA, and DMA. The procedures for analyzing As(III), As(V), MMA, and DMA followed closely those in our previous study (Huang et al. 2003). The accuracy of the procedure was validated by the analysis of the standard reference material (SRM) BCR 627 tuna tissue. Total arsenic and DMA concentrations of SRM were $4.9 \pm 0.2 \mathrm{mg} / \mathrm{kg}$ and $1.8 \pm 0.1 \mu \mathrm{mol} / \mathrm{kg}$, respectively, which values were consistent with the certified values of $4.8 \pm 0.3 \mathrm{mg} / \mathrm{kg}$ and $2.0 \pm 0.3 \mu \mathrm{mole} / \mathrm{kg}$, respectively. The detection limits of total arsenic, $\mathrm{As}(\mathrm{II}), \mathrm{As}(\mathrm{V}), \mathrm{MMA}$, and DMA were $0.2,0.4,0.2,0.4$, and $0.3 \mu \mathrm{g} / 1$, respectively. Samples were spiked with arsenic species to calculate the recovery rate in every extraction step and laboratory procedure. The extraction recovery rates of $\mathrm{As}(\mathrm{III}), \mathrm{As}(\mathrm{V}), \mathrm{MMA}$, and DMA were $102.7 \pm 4.7 \%$, $104.1 \pm 6.8 \%, 104.7 \pm 6.5 \%$, and $98.0 \pm 7.1 \%$, respectively. The laboratory procedure recovery rates of total $\mathrm{As}, \mathrm{As}(\mathrm{III}), \mathrm{As}(\mathrm{V}), \mathrm{MMA}$, and DMA were $103.2 \pm 7.1 \%, \quad 100.7 \pm 3.8 \%, 97.2 \pm 4.0 \%, 104.9 \pm 4.6 \%$, and $97.2 \pm 4.0 \%$, respectively. The coefficient of variation was used to test the reliability and was less than 5\% for all experiments (Gomez-Ariza et al. 2000; Huang et al. 2003).

The samples of mullet tissues, including muscle, stomach, ovary and testis, were grouped by the growth types. Analysis-of-variance (ANOVA) was applied to examine the statistical differences between the dependent variables - the total As content and the content of each As species in the mullet tissues - with the growth types (aquacultural or wild). A 0.01 level of significance $(\alpha=0.01)$ was used to determine whether the mean concentrations of total As and particular As species in mullet tissues differ between the aquacultural and wild types.

\section{RESULTS AND DISCUSSION}

Table 1 presents the means and standard deviations of total As and As species of 
Table 1. Total As content and content of each As species in four edible tissues of aquacultural and wild mullet (mean \pm standard deviation; $\mu \mathrm{g} / \mathrm{g}$ ).

\begin{tabular}{clcllll}
\hline tissues & $\begin{array}{l}\text { growth } \\
\text { type }\end{array}$ & total As & As(III) & As(V) & DMA & MMA \\
\hline muscle & $\mathrm{A}$ & $2.38 \pm 0.78^{*}$ & $0.008 \pm 0.004$ & $0.051 \pm 0.025^{*}$ & $0.029 \pm 0.024^{*}$ & $0.003 \pm 0.003^{*}$ \\
& $\mathrm{~W}$ & $4.18 \pm 1.12^{*}$ & $0.008 \pm 0.006$ & $0.022 \pm 0.010^{*}$ & $0.088 \pm 0.047^{*}$ & $0.008 \pm 0.005^{*}$ \\
& $\mathrm{O}$ & $3.28 \pm 1.32$ & $0.008 \pm 0.005$ & $0.036 \pm 0.024$ & $0.058 \pm 0.048$ & $0.006 \pm 0.005$ \\
\hline stomach $\mathrm{A}$ & $9.33 \pm 2.27^{*}$ & $0.337 \pm 0.171^{*}$ & $0.502 \pm 0.283^{*}$ & $0.583 \pm 0.209^{*}$ & $0.268 \pm 0.139^{*}$ \\
& $\mathrm{~W}$ & $5.37 \pm 0.67^{*}$ & $0.072 \pm 0.031^{*}$ & $0.113 \pm 0.032^{*}$ & $0.406 \pm 0.032^{*}$ & $0.028 \pm 0.009^{*}$ \\
& $\mathrm{O}$ & $7.35 \pm 2.60$ & $0.204 \pm 0.181$ & $0.308 \pm 0.280$ & $0.494 \pm 0.172$ & $0.148 \pm 0.156$ \\
\hline ovary & $\mathrm{A}$ & $6.52 \pm 0.48^{*}$ & $0.026 \pm 0.015$ & $0.049 \pm 0.009^{*}$ & $0.097 \pm 0.019^{*}$ & $0.029 \pm 0.001^{*}$ \\
& $\mathrm{~W}$ & $11.81 \pm 1.61^{*}$ & $0.025 \pm 0.008$ & $0.084 \pm 0.016^{*}$ & $0.282 \pm 0.024^{*}$ & $0.067 \pm 0.010^{*}$ \\
& $\mathrm{O}$ & $9.17 \pm 2.99$ & $0.025 \pm 0.011$ & $0.066 \pm 0.022$ & $0.189 \pm 0.099$ & $0.048 \pm 0.021$ \\
\hline testis & $\mathrm{W}$ & $12.94 \pm 0.98$ & $0.032 \pm 0.009$ & $0.103 \pm 0.005$ & $0.693 \pm 0.050$ & $0.031 \pm 0.005$ \\
\hline
\end{tabular}

${ }^{\mathrm{a}} \mathrm{A}$ : aquacultural; $\mathrm{W}$ : wild; $\mathrm{O}$ : overall

"significant difference between aquacultural and wild mullet ( $p$-value $<0.01$ )

12 sets of mullet samples in four edible tissues of aquacultural and wild mullet.

The total As contents in the four tissues follow the order testis > ovary $>$ stomach $>$ muscle. The mean total As contents of the testis, ovary, stomach and muscle are $12.94,9.17,7.35$ and $3.28 \mu \mathrm{g} / \mathrm{g}$ (dry), respectively. These results are similar to those of Kirby and Maher (2002) and Maher et al. (1999), who investigated mullet in the seas around Australia. The contents of As(III), As(V) and MMA in the stomach of mullet significantly exceed those in other tissues of mullet $(p<0.01)$. The DMA contents in four tissues of mullet differ significantly from each other $(p<0.01)$. The DMA content is the highest in the testis, with an average of $0.693 \mu \mathrm{g} / \mathrm{g}(\mathrm{dry})$, and that in the muscle is the lowest. The testis of male mullet has the highest total As content, the ovary of female mullet has the second highest, and the muscle has the lowest.

Figure 1 shows distributions of the total As and each As species in four edible tissues of mullet for different growth types. The testis and ovary of wild mullet have the highest and the second highest total As content. The muscle of aquacultural mullet had the lowest total As content. The total As, DMA and MMA contents in the muscle of wild mullet exceed those of aquacultural mullet. The total As, As (V), DMA and MMA contents in the ovary of wild mullet also exceed those of aquacultural mullet. Only the $\mathrm{As}(\mathrm{V})$ contents in the muscle of aquacultural mullet are larger than those of wild mullet and the As(III) contents in 


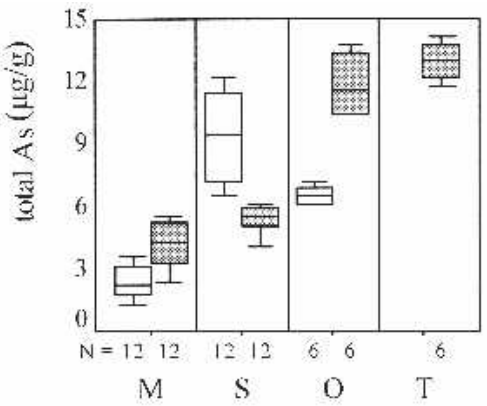

(A)

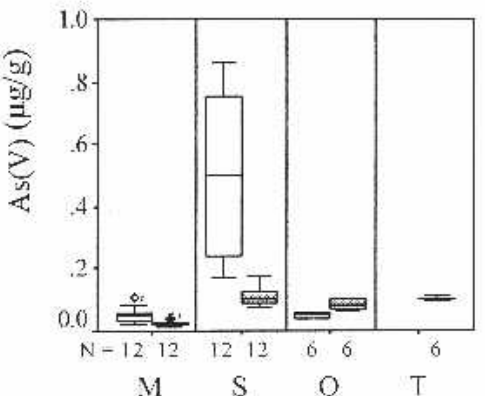

(C)

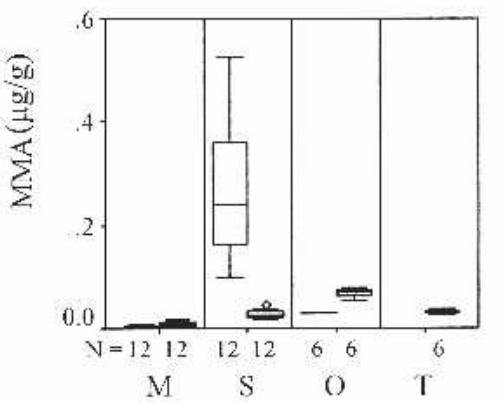

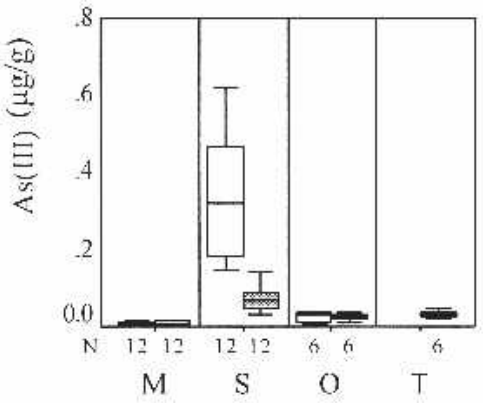

(B)

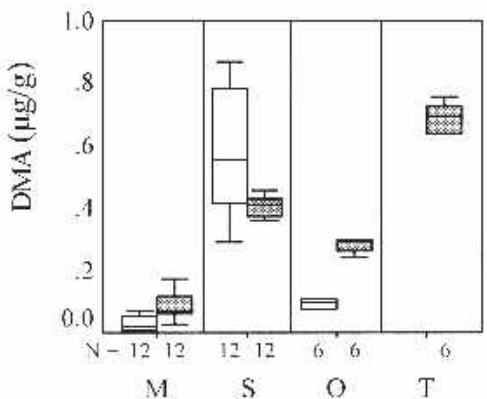

(D)

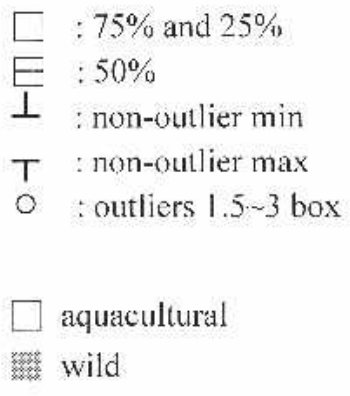

(E)

Figure 1. Box-Whisker plots of (A) total As, (B) $\mathrm{As}(\mathrm{III})$, (C) As(V), (D) DMA and (E) MMA in four edible tissues of aquacultural and wild mullet. $M$ is the muscle; $\mathrm{S}$ is the stomach; $\mathrm{O}$ is the ovary; and $\mathrm{T}$ is the testis.

the muscle and ovary do not differ significantly between aquacultural and wild mullet. IIowever, the total $A$ s and all As species contents in the stomach of aquacultural mullet significantly exceed those of wild mullet. Therefore, the different growth types significantly affect the As species contents in mullet.

The relationship between the accumulation of As in mullet tissues and its living 
environment was examined first. The mean total As concentration in the pond water is $49 \mu \mathrm{g} / \mathrm{L}$, which is close to the aquacultural water quality standard of As, $50 \mu \mathrm{g} / \mathrm{L}$ (Taiwan EPA, http://www.epa.gov.tw/). The total As concentrations in ponds greatly exceed that in the sea, $1 \sim 5 \mu \mathrm{g} / \mathrm{L}$. The analytical result demonstrates that the As contents in the tissues of mullet are not correlated with those in the environment, so a high As content in water does not cause a large As content to accumulate in mullet. The total As content in the stomach of aquacultural mullet exceeds that of wild mullet $(\mathrm{p}<0.01)$, whereas the total As contents in the muscle and ovary of wild mullet exceed those of aquacultural mullet $(\mathrm{p}<0.01)$.

Mullet is a benthic feeding fish. The major paths of accumulation of As species in mullet tissues are through the gills and the diet (Maher et al. 1999). Sediment is ingested when a mullet eats. The total As concentrations in pond sediment which range from 20.2 to $44.9 \mu \mathrm{g} / \mathrm{g}$ in the areas of hyperendemic blackfoot disease markedly exceed those in sea water that is unpolluted by As (Wang 2003). The high total As concentrations in the pond sediment are associated with a long-term use of endemic groundwater with high As content. Mullet lives in an environment of high As, resulting in a large number As content to be accumulated in its ingestion tissue. Maher et al. (1999) and Kirby and Maher (2002) indicated that a high proportion of inorganic As contents among As species is present in the ingestion tissue of mullet.

Figures 1 (B) and (C) also show that the stomach of aquacultural mullet has a significantly high inorganic As content. The total As contents in the muscle and ovary of wild mullet exceed those of aquacultural mullet.

In Taiwan, aquacultural mullet is typically farmed in fresh water or semi-salt water, and wild mullet grows in sea water. The As contents in fresh fish are usually much lower than those in sea fish (Francesconi and Kuehnelt 2002). Larsen and Francesconi (2003) showed that the accumulation of As in teleost fish is correlated positively with salinity. That is, high As accumulation in teleost fish is consistent with high salinity (Larsen et al. 2002), which result is similar to that herein.

After mullet has ingested organic sediment, the As (V) contents in the stomach of mullet increases. Arsenic in the body of a mullet is generally transported into various tissues through the blood. Sea animals have detoxification mechanisms that remove toxic substances, such as the transformation of $\mathrm{As}(\mathrm{V})$ and $\mathrm{As}(\mathrm{III})$ to MMA and DMA, to protect biological cells (Maher and Butler 1988; Tamaki and Frankenberger 1992). DMA has been shown to consist of $62 \%$ the total As content of blood in mullet (Maher et al. 1999). Figure 1 (D) plots the DMA distributions in mullet tissues. The DMA contents in each tissue exceed contents of other As species. The source of the high DMA content is attributable to the methylation of inorganic As species. Other sources are the degradation of AsB in food that is mixed with bacteria and enzymes in the digestion system (Hanaoka 
et al. 1991) and the ingestion of waterweed that contains a large amount of AsB (Edmonds and Francesconi 1993).

The accumulation of As in mullet is closely correlated with its ingestion habits and the level of salinity. It is not correlated with the concentration of As in the water. Although total As concentration in ponds in areas of hyperendemic blackfoot disease is close to the allowed maximum As concentration in aquacultural water, a high content in pond sediment is responsible for high total As and inorganic As contents in the stomach of aquacultural mullet. However, As contents in other edible tissues of aquacultural mullet are lower than those of wild mullet. Therefore, the allowed concentration of As in aquacultural water must be revised and the As content in the sediment showed be regarded as another important factor that affects the As content in mullet.

Acknowledgment. We thank the National Science Council of the Republic of China for financially supporting this research under Contract No. NSC 93-2313-B-002-071.

\section{REFERENCES}

Chang CF, Lan SC, Pan BS (1995) Feed administration of estradiol-17-beta stimulates female differentiation in juvenile grey mullet mugil cephalus. Zool Stud 34: 257-264

Edmonds JS, Francesconi KA (1993) Arsenic in seafood: human health-aspects and regulations. Mar Pollut Bull 26: 665-674

Francesconi KA, Kuehnelt D (2002) Arsenic compounds in the environment. In: Environmental Chemistry of Arsenic; William T. and Frankenberger, J.R.,Ed.,Marcel Dekker Inc: New York, Chapter 3, 51-94

Gomez-Ariza JK, Sanchez-Rodas D, Giraldez I, Morales E (2002) Comparison of biota sample pretreatments for arsenic speciation with couple HPLC-HG-ICP-MS. Analyst 125: 401-407

Huang YK, Lin KH, Chen HW, Chang CC, Liu CW, Yang MH, Hsueh YM (2003) Arsenic species contents at aquaculture farm and in farmed mouthbreeder (Oreochromis Mossambicus) in blackfoot disease hyperendemic areas. Food Chem Toxicol 41: 1491-1500

Hanaoka K, Motoya T, Tagawa S, Kaise T (1991) Conversion of arsenobetaine by intestinal bacteria of a mollusk liolophura-japonica chitions. Appl Organomet Chem 5: 427-430

Kirby J, Maher W (2002) Tissue accumulation and distribution of arsenic compounds in three marine fish species: relationship to trophic position. Appl Organomet Chem 16: 108-115

Larsen EH, Andersen NL, Moller A, Petersen A, Mortensen GK, Petersen J (2002) Monitoring the content and intake of trace elements from food in Denmark. Food Add Contam 19: 33-46

Larsen EH, Francesconi KA (2003) Arsenic concentrations correlate with salinity 
for fish taken from the North Sea and Baltic waters, Mar Bio Assoc UK 83: 283-284

Maher W, Butler E (1998) Arsenic in the marine environment. Appl Organomet Chem 2: 191-214

Maher W, Goessler W, Kirby J, Raber G (1999) Arsenic concentrations and speciation in the tissues and blood of sea mullet (Mugil cephalus) from Lake Macquarie NSW, Australia. Mar Chem 68: 169-182

Tamaki S, Frankenverger WT (1992) Environmental biochemistry of arsenic. Rev Environ Contam Toxicol 124: 79-110

Wang SW (2003) Effect of sediments on the distribution of arsenic species in aquacultural ecological system of blackfoot disease areas. MS Thesis, Dept Bioenviron Sys Eng, National Taiwan Univ, Taipei, Taiwan 